ГРОМОВА

Ольга Свгеніївна

kuprienkoolga80@gmail.com

к.е.н., дочент, Віннииький торговельно-економічний інститут KHTEУ
УДК 339.138:004.738.5

КОЗЛОВ

Олександр Юрійович sanyakozlovsk777@gmail.com
Віннииький торговельноекономічний інститут КНТЕУ

\title{
RESEARCH ON THE USE OF MARKETING INSTRUMENTS INFLUENCE ON CONSUMER BEHAVIOR ON THE EXAMPLE OF BOMBA-TOUR LLC, VINNYTSIA
}

HROMOVA Olha Yevheniivna - PhD in Economics, Associate Professor, Vinnytsia Trade and Economic Institute of KNTEU

KOZLOV Oleksandr Yuriiovych - Vinnytsia Trade and Economic Institute of KNTEU

У статті досліджено використання маркетингових інструментів впливу на поведінку споживачів на прикладі ТОВ «Бомба-тур» м. Вінниия. Наведена характеристика туристичної фірми ТОВ «Бомба-тур» м. Вінниия. Структуровано загальні елементи просування туристичної організації. Зазначені основні маркетингові інструменти просування ТОВ «Бомба-тур» у мережі Інтернет. Здійснена оцінка використання основних маркетингових інструментів та аналіз їх впливу на стан організачії. Сформульовані висновки з проведеного дослідження.

$$
\text { * * * }
$$

В статье исследовано использование маркетинговых инструментов влияния на поведение потребителей на примере ООО «Бомба-тур» г. Винница. Приведена характеристика туристической фирмь ООО «Бомба-тур» г. Винница. Структурированы основные элементы продвижения туристической организации. Указаны основные маркетинговые инструменты продвижения ООО «Бомба-тур» в сети Интернет. Осуществлена оценка использования основных маркетинговых инструментов и анализ их влияния на состояние организации. Сформулированы выводы из проведенного исследования.

$$
* * *
$$

The article explores the use of marketing tools to influence consumer behavior using the example of Bomba-Tour LLC in Vinnytsia. The characteristic of the tourist company Bomba-Tour LLC, Vinnitsa, is given. The elements of promoting a tourism organization are structured. The main marketing tools for promoting Bomba-Tour LLC on the Internet are indicated. Note that there is no methodology for assessing the effectiveness of marketing tools in the management of unstable systems, including the various phases of instability, dramatically reduces the importance of marketing as a way of influencing the financial condition of organizations, making it difficult to manage unstable systems in general and to achieve the effectiveness of their activities in particular. It can be stated that in recent years

Internet marketing tools have emerged that can be evaluated in real time, as well as tools for conducting market research on consumer preferences and market trends. Assessing the use of marketing tools and analyzing their impact on the state of the organization can ensure the adoption of only those marketing decisions and the implementation of those marketing tools that will ultimately affect the effectiveness of managing unstable systems.

There is a huge amount of information on various marketing tools resources, but its uniformity causes a number of problems that need to be solved: the mass use by companies of the same methods of influencing the target audience, respectively, leads consumers to be distracted from messages from one channel; the use of popular, but not effective, methods leads to companies' lack of profitability and dissatisfaction with communications results. In view of the above issues, there is a need conducting research to identify low-cost but effective tools communication. The conclusions of the study are formulated.

Ключові слова: маркетинг, інструменти, вплив, поведінка, споживачі, туризм

Ключевые слова: маркетинг, инструменты, влияние, поведение, потребители, туризм

Keywords: marketing, tools, influence, behavior, consumers, tourism

\section{ПОСТАНОВКА ПРОБЛЕМИ}

У процесі управління організацією, як нестабільною системою, необхідно формування нових маркетингових стратегій, цілей і завдань, адекватну турбулентну ситуацію в організації. Для адаптації до нових умов потрібно використовувати інноваційні маркетингові інструменти та комунікаційні підходи у комплексі. Разом $з$ тим більшість організацій не тільки не використовують у своїй діяльності такі інструменти та підходи, а й не володіють достатніми науково-ме- тодичними та практичними навичками формування маркетингових стратегій, тактичних дій з вибору маркетингових інструментів. Ми вважаємо, що актуально для ефективного розвитку та просування туристичних організацій - це вдале використання та застосування маркетингових інструментів у діяльності підприємства.

META CTATTI полягає у грунтовному дослідженні використання маркетингових інструментів впливу на поведінку споживачів на прикладі ТОВ «Бомбатур» м. Вінниця. 
Проблеми застосування інструментів у маркетингу досліджувались у працях В.Д. Байкова, К. Вертайма, І.Л. Литовченко та В.П. Пилипчука, С.М. Ілляшенка, Н.С. Ілляшенко, Г.В. Мозгової, Ю.С. Шипуліної та ін.

\section{ВИКЛАД ОСНОВНОГО МАТЕРІАЛУ}

На початковому етапі формування маркетинг був інструментом, який вирішує питання просування продукту масового виробництва на ринок. Знеособлений продукт був призначений для всього ринку, незалежно від споживчих переваг окремих сегментів. Посилення конкуренції призводить до розуміння підвищення ролі маркетингу і формування нових маркетингових рішень, розвитку інструментального маркетингу; формуються стратегічні та оперативні напрямки у маркетингу.

Надалі приходить усвідомлення конкурентних переваг майна, які надають грамотні маркетингові рішення. Внаслідок чого компанії розширюють маркетингові служби і передають ім все більше повноважень, структурно і функціонально розвивається сама система маркетингу.
ТОВ «Бомба-тур» - команда професіоналів на ринку туристичних послуг, які постійно розвиваються, вдосконалюють спектр туристичних послуг, адаптують різні новинки й розробки у сфері туризму, а найголовніше - ТОВ «Бомба-тур» регулярно прислухаються до порад клієнтів і разом 3 ними розвивають туристичний ринок в напрямку поліпшення якості послуг і відпочинку. ТОВ «Бомба-тур» - це компанія, яка працює виключно в правовому полі: організація офіційно зареєстрована як юридична особа, має ліцензію на туроператорську діяльність з внутрішнього i міжнародного туризму, має банківську гарантію туроператора (забезпечення фінансової відповідальності перед туристами), тому подорожувати разом 3 ТОВ «Бомба-тур» завжди безпечно, комфортно, якісно і зручно.

Просування товарів і послуг в організації ТОВ «Бомба-тур» - це комплекс маркетингових інструментів, яка спрямований на стимулювання клієнтів до здійснення покупок путівок.

Способи реалізації елементів системи просування безпосередньо в компанії представлено у табл. 1.

Таблиця 1

\section{Елементи системи просування в ТОВ «Бомба-тур»}

\begin{tabular}{|c|c|}
\hline Елементи системи просування & Як реалізується на підприємстві \\
\hline Реклама & $\begin{array}{c}\text { Вивіски, інформація про актуальні путівки в друкованих виданнях, } є \text { реклами в } \\
\text { Інтернеті. }\end{array}$ \\
\hline Стимулювання збуту & Практикуються акції і розпродажі турів останньої миті \\
\hline Директ-маркетинг & Використовує при необхідності для інформування про конкретні персональні \\
пропозиіії
\end{tabular}

Основними факторами, що дають можливість підвищення конкурентоспроможності на ринку туристичних послуг для ТОВ «Бомба-тур», $є$ :

- напрацювання досвіду і умінь вести конкурентну боротьбу;

- ведення активної рекламної діяльності;

- введення нових напрямків туризму;

- розробка комплексу заходів стосовно просування туристичних послуг [1, с. 74].

ТОВ «Бомба-тур» $\epsilon$ комерційною організацією, яка має в якості основної мети своєї діяльності - отримання прибутку. Основною послугою фірми є продаж туристичних путівок за різними напрямками.

Діюча стратегія фірми - робота в туристичному бізнесі за поточними напрямками, скорочення розриву кількості реалізованих путівок у літній і зимовий сезони, забезпечення будь-якого споживача тільки якісними послугами.

Рекламна діяльність у мережі Інтернет, а саме Інтернет-маркетинг, на даний час грає важливу роль у конкурентоспроможності будь-якого підприємства, що надає послуги, в тому числі туристичних агентств. I оскільки підприємство ТОВ «Бомба-тур» найменш конкурентоспроможне саме в області рекламної активності, пропонується розробити стратегію просування за допомогою Інтернет-маркетингу з метою збільшення обсягу продажів, створення іміджу фірми і підвищення її впізнаваності [2].

Основними перевагами Інтернет-маркетингу є:

- широкий інформаційний канал, можливість масового звернення до широкої аудиторії;

- таргетинг - можливість цільового звернення до певної частини аудиторії;

- можливість точного і швидкого аналізу реакції аудиторії;

- доступність і гнучкість, робота 24 години на добу;

- інтерактивність, взаємодія споживача з продавцем;

- концентрація уваги споживача;

- створення, оновлення і постійне поповнення бази даних клієнтів;

- вимірність ефективності витрачених на Інтернет-маркетинг коштів за рахунок аналітики;

- низька вартість, Інтернет-просування набагато дешевше і ефективніше в порівнянні з традиційними 
засобами реклами [3].

Основні інструменти Інтернет-маркетингу найбільш ефективно використовувати в комплексі. Реалізувати комплексний Інтернет-маркетинг на ТОВ «Бомбатур» можна за допомогою:

1. Найманого Інтернет-маркетолога - це дозволить швидко підняти рівень маркетингу на підприємстві, але пошуки професіонала вимагають часу й до того ж немає гарантій, що підприємство отримає необхідний результат.

2. Інтернет-маркетингового агентства - це забезпечить гарантії результату, підтверджені договором і статистикою, до того ж над просуванням буде працювати не один фахівець, а ціла команда.

Таким чином, для підприємства ТОВ «Бомба-тур» більш доцільно скористатися послугами Інтернетмаркетингового агентства. На сьогоднішній день в Україні існує велика кількість Інтернет-маркетингових агентств, але варто врахувати, що більшість 3 них займаються окремими видами послуг з Інтернет просування. Однак $\epsilon$ і великі компанії, що займаються комплексним Інтернет-маркетингом, такі як [4]:

- Інтернет-агентство «Promodex»

- Інтернет-агентство «Vis-a-vis»

- Інтернет-агентство «Verstkovo»

- Інтернет-агентство «Web-machine»

- Інтернет-агентство «Polyarix»

Порівнявши пропозиції вищевказаних компаній і їх ціни, був зроблений вибір на користь Інтернетагентства «Promodex» (TOB «PROMODEX»). Компанія заснована кваліфікованими фахівцями і прагне, щоб спектр пропонованих послуг охоплював максимально широке коло споживачів, відповідаючи їхнім потребам і бажанням. На даний час основними видами діяльності Інтернет-агентства «Promodex» $\mathrm{\text {: }}$

- створення веб-сайтів будь-якої складності (візитки, корпоративні сайти, Інтернет-магазини, портали тощо);

- комплексне просування веб-сайтів;

- медійна та контекстна реклама;

- організація, медіапланування і проведення великих рекламних кампаній у мережі Інтернет [5].

Для ефективності інтернет-маркетингу ТОВ «Бомба-тур» пропонується зайнятися і веб-розробкою, i Інтернет-просуванням, - для цього необхідно продумати які саме інструменти Інтернет-маркетингу будуть задіяні.

1. Контекстна і банерна реклама (для цього також необхідний Landing page).

2. Пошукова оптимізація (необхідний якісний контент: блог, контент-маркетинг).

3. SMM-просування (спільноти в соціальних мережах) [6].

Активна інтернет-маркетингова діяльність також стане однією 3 конкурентних переваг туристичної фірми ТОВ «Бомба-тур», що дозволить стати більш конкурентоспроможною серед своїх основних конкурентів.

\section{ВИСНОВКИ}

Основними інструментами просування у мережі Інтернет, якими користується компанія, $\epsilon$ соціальні мережі: групи Facebook i Instagram. Щодня розміщується в групах інформація про новинки, путівки, новини, акції, гарячі путівки.

3 усіх вищевикладених елементів просування на ТОВ «Бомба-тур» в меншій мірі і найменш ефективно використовується Інтернет-маркетинг. Також виходячи 3 даних - можна зробити висновок, що слід удосконалювати систему просування саме за допомогою інструментів Інтернет-маркетингу.

\section{Список використаних джерел}

1. Багиев Г.Л. Маркетинг. Санкт-Петербург: Питер, 2010. $443 \mathrm{c}$.

2. Свтушевська О.В. Особливості поведінки споживачів на ринку в сучасних умовах. Інвестиції: практика та досвід. 2016. Bun. 20. C. 22-24.

3. Ілляшенко Н.C. SEO-оптимізація як сучасний інструмент Internet-маркетингу Маркетинг і менеджмент інновачій. 2012. Bип. 3. С. 63-74.

4. Ілляшенко С.М. Застосування маркетингових Internеt-технологій для формування іміджу організаиї: тези доповідей Х Міжнародної науково-практичної конференціі «Маркетинг та логістика в системі менеджменту». Львів: Видавничтво Львівської політехніки, 2014. С. 144-146.

5. Мозгова В.Г. Інструменти Internet-маркетингу та їх переваги для сучасних украӥнських підприємств. Ефективна економіка. 2013. Bun. 10. С. 79-86.

6. Окландер М.А. Сучасні трансформачії культурних чинників поведінки споживача. Економічний вісник Національного технічного університету України «Київський політехнічний інститут». 2013. Вип. 10. С. 386-392. URL: http://nbuv.gov.ua/UJRN/evntukpi_2013_10_65

\section{References}

1. Bagiev G.L. Marketing. Saint Petersburg: Peter, 2010. 443 p. (in Russian)

2. Yevtushevska O.V. Features of consumer behavior in the market in modern conditions. Investments: practice and experience. 2016. № 20. pp. 22-24. (in Ukrainian)

3.Illiashenko N.S. SEO-optimization as a modern tool of Internet-marketing Marketing and innovation management. 2012. № 3. pp. 63-74. (in Ukrainian)

4. Illiashenko S.M. Application of Internet marketing technologies for forming the image of the organization: abstracts of the X International Scientific-Practical Conference "Marketing and Logistics in the Management System". Lviv: Lviv Polytechnic Publishing House, 2014. pp. 144-146. (in Ukrainian)

5. Mozgova V.H. Internet Marketing Tools and Their Benefits for Modern Ukrainian Enterprises. Effective Economy. 2013. № 10. pp. 79-86. (in Ukrainian)

6. Auckland M.A, Modern transformations of cultural factors of consumer behavior. Economic Bulletin of the National Technical University of Ukraine "Kyiv Polytechnic Institute". 2013. № 10. pp. 386-392. URL: http://nbuv.gov.ua/UJRN/evntukpi_2013_10_65 (in Ukrainian) 